\title{
Effect of Human Resources Quality, Performance Evaluation, and Incentives on Employee Productivity at Raharja High School
}

\author{
Mulyati ${ }^{1}$, Selamat Zebua ${ }^{2}$, Mochamad Heru Riza Chakim ${ }^{3}$, Khairul $^{4}$ \\ ${ }^{1,2,3,4}$ University of Raharja, Modern, Jl. Jenderal Sudirman No.40, Cikokol, Kec. Tangerang, Kota \\ Tangerang, Banten 15117 \\ ${ }^{1}$ mulyati@raharja.info, ${ }^{2}$ selamat.zebua@ raharja.info, ${ }^{3}$ heru.riza@ raharja.info, ${ }^{4}$ khairul.rodjik@ raharja.info
}

\section{Article Info}

\section{Article history:}

Received 11-24-2022

Revised 12-29-2022

Accepted 01-02-2023

\section{Keywords:}

HR Quality

Performance Evaluation

Incentives

Productivity

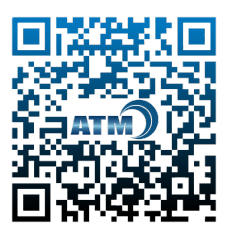

\begin{abstract}
This study used a sample of 30 employees of Raharja College, Cikokol, Tangerang which were taken randomly to test the effect of the quality of human resources, job evaluation, incentives on employee productivity. The survey method with path analysis technique was used to analyze the pattern of relationships between variables with the aim of knowing the direct or indirect effect of a set of independent variables (exogenous) on the dependent variable (endogenous) with data analysis using the smart PLS 3.0 version software. The results show that the quality of human resources has a positive effect on employee productivity with a path coefficient value of 0.145 , the quality of human resources has a positive effect on incentives with a path coefficient value of 0.121 , incentives have a positive effect on productivity with a path coefficient value of 0.784 , while performance evaluation has no positive effect on employee productivity with a path coefficient value of -0.103 . It can be said that all the hypotheses in this study only one that does not have a positive effect while the rest have a positive effect. From the results of the data analysis, it can be seen that the quality of human resources directly affects employee productivity at Raharja College. Thus, the hypothesis which states that the quality of HR has a direct effect on employee productivity is accepted.
\end{abstract}

This is an open access article under the CC BY-SA license.

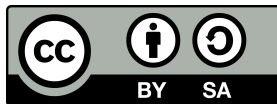

Corresponding Author:

Mulyati

University of Raharja, Tangerang, Indonesia

Email: mulyati@raharja.info

\section{INTRODUCTION}

The quality of human resources can be improved through the use of effective performance appraisal strategies and mechanisms. Performance appraisal is carried out to motivate and improve employee performance so that the company's development can be known [1]. The targets of the performance appraisal include the skills and abilities of employees in carrying out a task or job that is evaluated periodically, oriented to the past or the future, being objective, and using certain benchmarks. Therefore, companies need to know the weaknesses and strengthen the strengths to increase employee productivity [2].

One of the steps taken by the company to increase employee productivity and achieve maximum performance is by providing incentives. Incentives are a form of appreciation from company leaders in the form of money with the aim of motivating employees so that they can excel [3]. 
From this definition, it is clear that the provision of incentives is the provision of basic wages and salaries with the aim of increasing employee motivation. The provision of incentives can be in the form of financial incentives, namely money, bonuses, commissions, compensation for old-age benefits, overtime, and social security [4]. In addition, the provision of incentives can be in the form of non-financial as annual leave, awarding degrees, and thanks [5]. With incentives, employees are motivated to work diligently and enthusiastically with full responsibility so as to increase their productivity. From this explanation, the formulation of the problem:

1. Does the quality of human resources affect the productivity of Raharja College employees?

2. Does the quality of human resources directly affect incentives?

3. Does job evaluation have a direct effect on employee productivity at Raharja College?

4. Does job evaluation have a direct effect on incentives?

5. Does the provision of incentives directly affect the productivity of Raharja College employees?

\section{RESEARCH METHOD}

The relationship model between research variables is as follows:

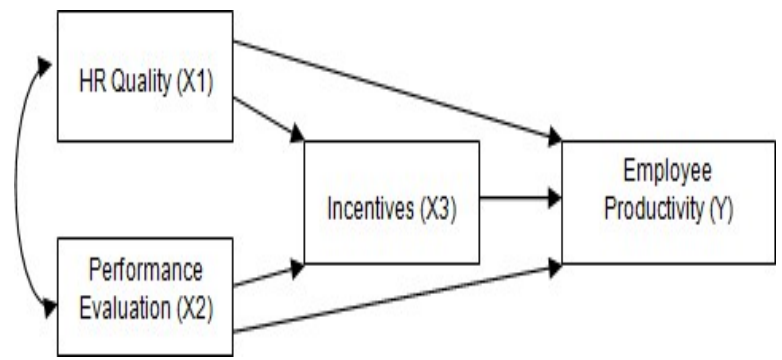

Figure 1. Theoretical Model of Relationship Between Research Variables

The survey method with path analysis technique is used to analyze the pattern of relationship between variables with the aim of knowing the direct and indirect effect of a set of independent variables (exogenous) on the dependent variable (endogenous) [6]. The population in this study were all employees of Raharja College, Cikokol, Tangerang with a sample of 30 employees who were taken randomly. Data analysis using smart PLS 3.0 version software [7].

\subsection{Literature Review}

\subsubsection{Quality of Human Resources}

Technology and science require humans to adapt and follow these advances in order to be able to compete with others. Those who are able to compete are human beings who are aware of the change (sense of change) and are able to see the future [8]. In order to be able to compete, quality human resources are needed. Quality human resources are human beings who have faith, knowledge (science and technology), charity, and are capable both physically and mentally [9]. Quality human resources Yun Iswanto and Adhie Yusuf are Human resources who master science and technology and have faith and piety. From the two definitions above, it can be said that qualified human resources are those who have knowledge, skills, and faith [10]. Gordon in Sutrisno quality resources must have the following competencies:

1. Knowledge, namely the ability to identify good ways of learning and learning processes as needed.

2. Understanding (understanding) is the depth of affective and cognitive.

3. Skill (ability), namely the ability to perform a task or job.

4. Value (value), namely the value of honesty, democratization, and others. 
5. Attitude (attitude) is a reaction (feeling) to external stimuli such as an attitude towards a salary increase or other.

6. Interest (attitude) is the individual's tendency to do a job

\subsubsection{Performance Evaluation}

The term evaluation means assessment [11]. The definition of evaluation introduced by Stufflebeam in Lalaba is "The process of obtaining, delineating, and providing useful information for judging decision alternatives". interpreted as the process of obtaining, describing, and providing information to assess decision alternatives. Meanwhile, Arikunto defines evaluation as the process of collecting data or information on his work to be rewarded or compensated [12]. The performance indicators commonly used are performance indicators of input (input), output (output), results (outcomes), benefits (benefits), and impact (impact). He also said that the conditions that must be met for a performance indicator are 1) clear and specific; 2) can be measured objectively, qualitatively, and quantitatively; 3) deal with relevant aspects; 4) important and useful; 5) flexible and sensitive to changes in implementation; 6) effective and efficient [13].

Performance evaluation is carried out to determine and measure the progress of work carried out by an employee. This is needed so that performance can be achieved optimally in accordance with the standards set. Performance measurement is a management tool to assess or evaluate success or failure in achieving company goals and objectives [14]. aspects of measurement include the determination of performance indicators and the determination of the results of the achievement of performance indicators. Performance measurement must be carried out regularly so that improvement actions can be taken such as improving performance that is still low, improving better relations between staff and management, and increasing closer relationships with customers [15].

The key elements of performance measurement are the establishment of plans, goals, objectives, strategies for achieving goals, development of relevant measurement systems, use of information, and reporting of results normally. The way to measure performance is by:

1. planned performance compared to actual performance.

2. results or goals compared to actual performance.

3. the results of this year's performance compared to the performance of previous years.

4. the company's performance compared to the results of the performance of similar companies, and

5. actual performance compared to predefined standards.

\subsubsection{Incentives}

Incentives are direct wages outside of salaries. Hariandja, incentive is an award related to work performance [16]. The higher the work performance, the greater the incentives received. Incentives are positive motivators for employees to increase their passion, creativity and develop themselves to become professional workers. This is in line with the opinion of Jensen and Meckling in Hariandja, incentives are used to provide motivation so that employees can improve their work both in quality and quantity [17]. Indicators of providing incentives include:

1. piecework: the provision of financial incentives by using the size of the production unit,

2. bonus: providing incentives if employees can exceed the set targets,

3. commission

4. maturity: commission for technical/professional staff.

Manullang explains that incentives can be grouped into three groups: material incentives, namely all incentives in the form of money; Semi material incentives (semi-material incentives) are all types of incentives that cannot be valued with money such as promotions, permanent employees, proper placement, and pleasant working conditions [18]. 


\subsubsection{Employee Productivity}

Work productivity plays an important role in determining the continuity of the company. Employee productivity is a comparison between employee participation per unit time and the results achieved. In this sense, it shows that there is a relationship between work results and the time needed to produce products from an employee [19]. Productivity is the relationship between input (input) and output (output) of a productive system, while Sinungan in Rindi Andika productivity is defined as the relationship between real and physical results. Productivity is the efficiency of using resources to produce output. From this expression, the benchmarks for increasing employee productivity can be seen from 1) using the same resources can increase the amount of production, 2) the same amount of production using reduced resources, 3) the amount of production is greater with additional resources relatively smaller [20].

Productivity is a relationship between the output achieved and the resources used in carrying out a particular activity. Employee work productivity is created not by itself but must be strived for by employees so that it can be what is requested by the company from the work done and is willing to carry out what is charged to employees. Therefore, companies must foster work enthusiasm and work enthusiasm in employees so that their work productivity is higher.

States that the elements that affect productivity are efficiency, effectiveness, and quality. To measure productivity can be done in two ways, namely operational productivity and financial productivity. Operational productivity is a physical measure of input and output expressed in physical units, while financial productivity measures use units of money for inputs.

To increase work productivity, it is necessary to assess work targets which consist of aspects of quantity, namely the number of achievements in a certain volume of units or sizes, quality, namely quality achievements in accordance with predetermined standards, time, namely the range of achievements in minutes, hours, days, weeks, months, and years, as well as the cost aspect, namely the nominal amount that must be spent.

\subsection{Hypotheses}

Based on the theoretical study that has been described, the researcher proposes a research hypothesis as follows: H1: The quality of human resources has a direct effect on employee productivity.

H2: The quality of human resources has a direct effect on incentives.

H3: Performance evaluation has a direct effect on employee productivity.

H4: Performance evaluation has a direct effect on incentives

H5: Incentives have a direct effect on employee productivity.

\section{RESULT AND DISCUSSION}

The first data analysis was carried out to test the validity of the objectives in order to produce the validity of each indicator as a prerequisite for proceeding to the analysis model. The results of the convergent validity can be seen in table 1 . All indicators that are declared valid are in accordance with the provisions that the magnitude of the convergent validity value is 0.5 . The use of AVE to assess a convergent variable of good validity of at least 0.5 means that latent can explain the average of more than half the variance of the indicator. 


\begin{tabular}{|c|c|c|c|c|}
\hline \multicolumn{5}{|c|}{ Outer Loadings } \\
\hline & INS & KIN & PROD & SDM \\
\hline INS1 & 0,65 & & & \\
\hline INS2 & 0,61 & & & \\
\hline INS3 & 0,63 & & & \\
\hline INS4 & 0,51 & & & \\
\hline INS5 & 0,65 & & & \\
\hline KIN1 & & 0,58 & & \\
\hline KIN2 & & 0,62 & & \\
\hline KIN3 & & 0,65 & & \\
\hline KIN4 & & 0,62 & & \\
\hline KIN5 & & 0,64 & & \\
\hline PROD1 & & & 0,65 & \\
\hline PROD2 & & & 0,62 & \\
\hline PROD3 & & & 0,53 & \\
\hline PROD4 & & & 0,60 & \\
\hline SDM1 & & & & 0,62 \\
\hline SDM2 & & & & 0,63 \\
\hline SDM3 & & & & 0,65 \\
\hline SDM4 & & & & 0,67 \\
\hline SDM5 & & & & 0,63 \\
\hline
\end{tabular}

The second data analysis is to test the reliability of the goal in order to produce the reliability of each indicator as a prerequisite to proceed to model analysis. The results of Construct Reliability and Validity can be seen in table 2 . All indicators are declared reliable in accordance with the provisions of the reliability value of 0.5 . 


\begin{tabular}{|c|c|c|c|c|}
\hline \multicolumn{5}{|c|}{ Construct Reliability and Validity } \\
\hline & Cronbac h's Alpha & rho_A & Composite Reliability & Average Variance Extracted (AVE) \\
\hline INS & 0,64 & 0,65 & 0,66 & 0,54 \\
\hline KIN & 0,65 & 0,65 & 0,67 & 0,56 \\
\hline PROD & 0,62 & 0,63 & 0,64 & 0,526 \\
\hline SDM & 0,63 & 0,62 & 0,67 & \\
\hline
\end{tabular}

The third data analysis is to examine the model relationship between latent variables in which there are three important components that are generated as shown in Figure 2 below. First, the loading factor shows a high value above 0.7 , meaning that all indicators of the variables are proper and fit to the model. Second, the coefficient value of the path relationship between exogenous and endogenous variables shows varying coefficient values including the relationship between $\mathrm{HR} \rightarrow \mathrm{INS}$ of $0.121, \mathrm{HR} \rightarrow \mathrm{PROD}$ of $0.145, \mathrm{KIN} \rightarrow$ INS of $0.790, \mathrm{KIN} \rightarrow$ PROD of -0.103 , and INS $\rightarrow$ PROD of 0.784 . Third, the R Square value of the endogenous INS variable is 0.769 and PROD is 0.635 .

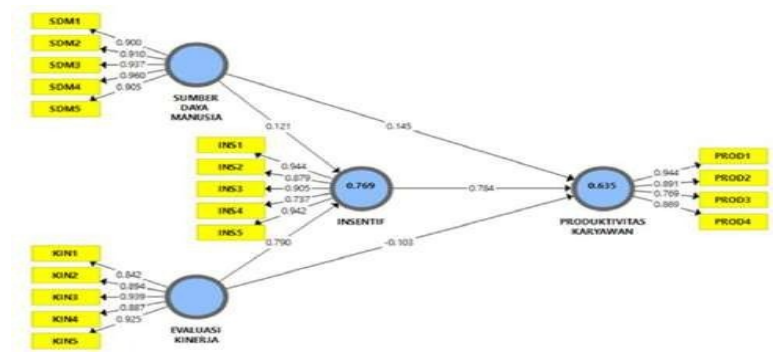

Figure 2. Theoretical Model of Relationship Between Research Variables

Figure two above shows Convergent Validity (outer loading), where all the outer loading values between latent variables and indicators are greater than 0.7 , meaning that the variable has an absolute correlation with the value of each indicator that has met the validity requirements and is eligible to be used as further research and analysis.

The value of R Square in the endogenous construct (the dependent variable) has an incentive determination value (INS) of 0.769 meaning that there are $76.9 \%$ of factors that can affect the independent variable (exogenous) the rest are not mentioned in this study, while the Employee Productivity (PROD) is 0.635 it means that there are as many as $63.5 \%$ of factors that can affect the independent variables (exogenous) the rest are not mentioned in this study. It can be concluded that the weight of the R Square value substantively the latent variable has a high level of influence on the level of determination.

Furthermore, Figure 2 above of the Path Coefficients (path coefficients) shows the positive value relationship is in the range -1 to 1 , each SDM-INS is 0.121 , SDM to PROD is 0.145 , KIN to INS is 0.790 , KIN is to PROD of -0.103 , and INS to PROD of 0.784 . Thus, it can be said that all the hypotheses in this study are only one that does not have a positive effect while the rest have an influence.

\section{CONCLUSION}

Based on data analysis with path analysis, conclusions are drawn:

1. From the results of the data analysis, it can be seen that the quality of human resources directly affects employee productivity at Raharja College. Thus, the hypothesis which states that the quality of HR has a direct effect on employee productivity is accepted

2. From the results of data analysis conducted, the quality of human resources has a direct effect on incentives. Thus, the hypothesis that the quality of human resources has a direct effect on incentives is accepted.

3. From the results of the data analysis conducted that performance evaluation has no direct effect on employee productivity. Thus, the hypothesis that performance evaluation has a direct effect on employee 
productivity is not accepted

4. From the results of the data analysis conducted that performance evaluation has a direct effect on incentives. Thus, the hypothesis that performance evaluation has a direct effect on incentives is accepted

5. From the results of data analysis conducted that incentives have a direct effect on employee productivity. Thus, the hypothesis that incentives have a direct effect on employee productivity is accepted.

\section{REFERENCES}

[1] H. Shrouf, S. Al-Qudah, K. Khawaldeh, A. Obeidat, and A. Rawashdeh, "A study on relationship between human resources and strategic performance: The mediating role of productivity," Manag. Sci. Lett., vol. 10, no. 13, pp. 3189-3196, 2020.

[2] N. Kusumaning Putri, "PENGARUH GAYA KEPEMIMPINAN TRANSFORMASIONAL, BUDAYA ORGANISASI, MOTIVASI KERJA, DAN DISIPLIN KERJA TERHADAP PRODUKTIVITAS KERJA PADA PT. DASAR KARYA UTAMA TEMPURAN.” Skripsi, Universitas Muhammadiyah Magelang, 2019.

[3] D. Wulandari, E. Risdianto, F. Masito, I. Setiawan, and R. Efendi, "Analysis of E-Module Development Needs on the Topic of Quantity and Units at High Schools in Payakumbuh," JMKSP (Jurnal Manajemen, Kepemimpinan, dan Supervisi Pendidikan), vol. 7, no. 1, pp. 210-227, 2022.

[4] R. N. Wurarah, E. Timotius, T. B. Sembiring, and A. A. N. G. Sadiartha, "THE ROLE OF EMPLOYEE PERFORMANCE IN THE TOURISM HOSPITALITY INDUSTRY IN INDONESIA,” Acad. Strateg. Manag. J., vol. 20, no. 1, pp. 1-11, 2021.

[5] M. Aboramadan, B. Albashiti, H. Alharazin, and K. A. Dahleez, "Human resources management practices and organizational commitment in higher education: The mediating role of work engagement," Int. J. Educ. Manag., 2020.

[6] A. Thudaa, J. Sarib, and A. Maharanic, "Employees Perception of Human Capital Practices, Employee's Productivity, and Company Performance,” Integr. J. Bus. Econ., vol. 15, pp. 240-250, 2019.

[7] G. Anwar and N. N. Abdullah, "The impact of Human resource management practice on Organizational performance,” Int. J. Eng. Bus. Manag., vol. 5, 2021.

[8] N. Saffar and A. Obeidat, "The effect of total quality management practices on employee performance: The moderating role of knowledge sharing," Manag. Sci. Lett., vol. 10, no. 1, pp. 77-90, 2020.

[9] W. T. Ngwa, B. S. Adeleke, E. K. Agbaeze, N. C. Ghasi, and B. O. Imhanrenialena, "Effect of reward system on employee performance among selected manufacturing firms in the Litoral region of Cameroon," Acad. Strateg. Manag. J., vol. 18, no. 3, pp. 1-16, 2019.

[10] S. HAERANI, S. SUMARDI, W. HAKIM, H. HARTINI, and A. H. P. K. PUTRA, "Structural model of developing human resources performance: Empirical study of Indonesia states owned enterprises," J. Asian Financ. Econ. Bus., vol. 7, no. 3, pp. 211-221, 2020.

[11] Q. Aini, I. Dhaniarti, and A. Khoirunisa, "Effects of ilearning media on student learning motivation," Aptisi Trans. Manag., vol. 3, no. 1, pp. 1-12, 2019.

[12] E. Guustaaf, U. Rahardja, Q. Aini, H. W. Maharani, and N. A. Santoso, "Blockchain-based Education Project," Aptisi Trans. Manag., vol. 5, no. 1, pp. 46-61, 2021.

[13] Q. Aini, A. Alwiyah, and D. M. Putri, "Effectiveness of Installment Payment Management Using Recurring Scheduling to Cashier Performance," Aptisi Trans. Manag., vol. 3, no. 1, pp. 13-21, 2019.

[14] F. Agustin, Q. Aini, A. Khoirunisa, and E. A. Nabila, "Utilization of Blockchain Technology for Management E-Certificate Open Journal System,” Aptisi Trans. Manag., vol. 4, no. 2, pp. 133-138, 2020. 
[15] A. C. Purnomo, B. Pramono, and F. P. Oganda, "Design of Information System in Admission of New Students Based on Web in SMK Al Amanah,” Aptisi Trans. Manag., vol. 3, no. 2, pp. 159-167, 2019.

[16] S. Sayyida, S. Hartini, S. Gunawan, and S. N. Husin, "The impact of the COVID-19 pandemic on retail consumer behavior," Aptisi Trans. Manag., vol. 5, no. 1, pp. 79-88, 2021.

[17] F. Agustin, S. Syafnidawati, N. P. L. Santoso, and O. G. Amrikhasanah, "Blockchain-based Decentralized Distribution Management in E-Journals," Aptisi Trans. Manag., vol. 4, no. 2, pp. 107-113, 2020.

[18] Q. Aini, N. Lutfiani, N. P. L. Santoso, S. Sulistiawati, and E. Astriyani, "Blockchain For Education Purpose: Essential Topology,” Aptisi Trans. Manag., vol. 5, no. 2, pp. 112-120, 2021.

[19] M. A. Mumen, F. P. Oganda, N. Lutfiani, and I. Handayani, "Implementation of OJS based iJC media E-journal system at university of pramita Indonesia,” Aptisi Trans. Manag., vol. 4, no. 2, pp. 168-177, 2020.

[20] U. Rahardja, F. Andriyani, and T. Triyono, "Model Scheduling Optimization Workforce Management Marketing," APTISI Trans. Manag., vol. 4, no. 2, pp. 92-100, 2020. 